\title{
Explaining Turkey's emergence and sustained competitiveness as a full-package supplier of apparel
}

\author{
Binnur Neidik, Gary Gereffi \\ Department of Sociology, Duke University, Durham, NC 27708-0088, USA; \\ e-mail: bneidik@gmail.com,ggere@soc.duke.edu \\ Received 8 April 2005; in revised form 2 December 2005
}

\begin{abstract}
By using the main insights of the global value chains perspective and some of its critiques, we attempt to explain how Turkey has developed and sustained its export success as a full-package supplier of apparel during the 1990s and early 2000s. Towards this end, we first analyze the global dynamics that have facilitated Turkey's incorporation into global value chains and the development of full-package production. Second, we outline the key strategies which Turkish full-package suppliers have employed to meet international standards, typically associated with this export role. Third, we show that all of these developments have unfolded against a national context, unique features of which have further helped Turkey to sustain its competitiveness in this export role. Our analysis shows that, in the Turkish national context, more attention should be given to the role of business associations and the state.
\end{abstract}

\section{Introduction}

There have been diverse attempts in the globalization literature to account for the sustained export success of developing economies. One popular perspective, the global value chains (GVC) approach, focuses on the structure and dynamics of production and trade networks that connect local and foreign firms (Bair, 2002; Cheng and Gereffi, 1994). Emphasizing primarily the beneficial spillovers for local firms, this perspective hypothesizes that linking up with a particular set of foreign buyers leads to 'industrial upgrading', a process in which local firms gradually shift to increasingly complex, higher value-added forms of exporting by acquiring new capabilities. These shifts, in turn, are deemed essential to retaining a competitive edge in export industries (Gereffi and Memodovic, 2003).

Studies employing a GVC perspective have established that the shift from assembly to full-package exports has been the main upgrading challenge in labor-intensive industries such as apparel (Gereffi, 1999). In full-package supply, local contract manufacturers make finished goods that are sold under a foreign buyer's brand name. Although not as advantageous as the original-brand manufacturing role, in which firms design, market, and export their own-branded products, full-package supply generates more value than simpler roles, such as assembly, in which contract manufacturers make finished goods from imported inputs. This is because the full-package role requires manufacturers to coordinate the entire production process, including the procurement of raw materials.

The Turkish apparel industry provides a significant example of this transition. Turkey, which began exporting apparel in the 1980s, has emerged in the decades to follow as one of the largest exporters of apparel in the world. As highlighted in table 1, Turkey's apparel exports had reached a total value of US \$11.8 billion by 2005, making Turkey the fifth-largest exporter in the world, after China, Hong Kong, Italy, and Germany. In terms of net apparel exports, however, Turkey ranked even higher. With a net export value of US $\$ 11.045$ billion in 2005, Turkey came in 
Table 1. Top-ten net exporters of apparel: 2005 (US \$ million) (source: United Nations Comtrade data, http://unstats.un.org/unsd/comtrade).

\begin{tabular}{|c|c|c|c|}
\hline Country & Export value & Import value & Net value \\
\hline China & 74163 & 1629 & 72534 \\
\hline Turkey & 11833 & 788 & 11045 \\
\hline Hong Kong & 27292 & 18437 & 8856 \\
\hline India $^{a}$ & 6632 & 40 & 6592 \\
\hline Italy & 18502 & 12112 & 6390 \\
\hline Indonesia & 5106 & 71 & 5035 \\
\hline Mexico & 7271 & 2516 & 4754 \\
\hline Bangladesh $^{\text {a }}$ & 4442 & 129 & 4313 \\
\hline Romania & 4627 & 714 & 3913 \\
\hline Thailand & 4085 & 214 & 3872 \\
\hline Germany & 11818 & 24261 & -12443 \\
\hline United Kingdom & 4868 & 20987 & -16119 \\
\hline Japan & 495 & 22541 & -22045 \\
\hline United States & 4998 & 80071 & -75073 \\
\hline
\end{tabular}

second between China and Hong Kong. ${ }^{(1)}$ In this scheme of things, Turkey developed extensive full-package capabilities, emerging as one of the leading suppliers in this export category. Indeed, by the late 1990s, direct exports via the full-package role accounted for well over 90\% of Turkey's total apparel exports (Ateş, 1999). According to more recent estimates, this still continues to be the case (TGSD website, http://www.tgsd.org.tr).

Despite the significance of full-package exports for Turkey, there has been little attempt in the literature to account for how Turkey has emerged and remained competitive in this export role. Recent studies that incorporate a GVC perspective and explore the issue of upgrading in the Turkish case focus on individual firms, illustrating how these have made the transition from full-package supply to own-brand manufacturing (for example, Tokatlı and Eldener, 2004; Tokatlı and K1zılgün, 2004). The continuing importance of full-package exports, however, necessitates a detailed understanding of the sources of Turkey's competitiveness in this export role, which is the primary task we undertake in this paper. Such an examination should not only help to test the insights of the GVC perspective in a new setting, but also inform debates about the sustainability of Turkey's position in the period after the Multi-Fiber Arrangement (MFA), when Turkey began to face even stiffer competition from large full-package suppliers, such as India and China.

The GVC perspective has been subjected to several recent critiques that argue it should increase its scope. One of these criticisms targets the singular emphasis of the framework on the role of global buyers in accounting for upgrading outcomes. Another charge targets the narrow conceptualization, by the GVC approach, of the multilayered institutional context in which upgrading occurs (for example, Cutrini, 2003; Smith et al, 2003). Indeed, within the apparel industry, where trade regulations and regional integration schemes have been significant, the international dimension has been at the forefront of GVC analysis (Gereffi, 1999). The broader institutional context, however, has a national dimension, in which a range of state or nonstate actors can also be influential in shaping how local firms respond to global buyers (Hollingsworth et al, 1994; Smith et al, 2004).

(1) Meanwhile, the top-three net importers of apparel in 2004 were three of the world's leading advanced industrial economies - the United States (US \$70.7 billion), the United Kingdom (US \$14.9 billion), and Germany (US $\$ 12.9$ billion) (see table 1). 
Accordingly, in addition to examining value chain dynamics to explain Turkey's emergence and sustained competitiveness in the full-package supply role, we look at the national institutional context. In this respect, we emphasize primarily the role of the state and business associations in Turkey, highlighting the ways in which these have affected the adjustment of firms to competitive pressures. We conclude that upgrading depends not only on the capacity of firms, but also on institutional actors to create sources of competitive advantage (or disadvantage).

The paper is based on field research conducted in Turkey during 1996, 2001, and 2005 as well as on field research carried out in Germany (Turkey's largest export market) during 1996, 1997, and 2000. Face-to-face interviews were conducted with top executives, sourcing managers, representatives of industry associations, and labor unions. ${ }^{(2)}$ Additionally, we use local and international archival data gathered from both governmental and nongovernmental sources. These include statistical reports published by the host country governments, annual company reports, industry magazines, research reports prepared by local industry associations, news clippings, and other articles appearing in the mass media including the Internet (for additional details see Neidik, 2004a). Some of the current information about the companies cited in this paper has been gathered from company websites and from articles about the companies that have appeared in the mass media.

In what follows, we first provide an overview of the GVC perspective as well as some of its critiques to highlight how these theoretical debates frame our case. This is followed by a discussion of the international context, including Turkey's emergence as a full-package supplier and the role of global buyers. In the next section we outline the specific firm strategies through which full-package suppliers remained competitive in the 1990s and early 2000s, by using the insights of the GVC perspective. This is followed by a discussion of the national context, in which we highlight its peculiar features and how these features have further contributed to Turkey's competitiveness. The paper ends with a summary of key findings and raises issues about the future of the Turkish apparel industry.

\section{Export roles and upgrading challenges in GVCs}

The GVC framework has been employed to study the dynamics of export industries in diverse settings around the world (for example, Cruz-Moreira, 2003; Gereffi and Kaplinsky, 2001; Gereffi et al, 2005). A GVC refers to a transnational production system in which tiered networks of firms generate value by performing discrete, geographically dispersed, but interrelated economic activities. GVC analysis seeks to show how the configuration and dynamics of these production and trade networks create industrial upgrading opportunities for local firms in developing economies (Gereffi and Kaplinsky, 2001; Gereffi and Korzeniewicz, 1994).

GVC analysis draws attention to lead firms, which play the key role in setting up these production networks. Lead firms are generally the primary sources of material inputs, technology transfer, knowledge, and logistics, and they control access to the high value-added nodes in the network. In labor-intensive, consumer-goods industries, such as apparel and footwear, chains are 'buyer driven' because they are controlled by large retailers, designers, and other brand-name companies of international renown,

(2) Although we used a nonprobability sample of firms, we believe our findings can provide insight into the complexity of the Turkish case. It should be noted that the companies interviewed, especially those in Germany, are some of Europe's largest. These companies have extensive overseas production and sourcing networks, as well as long sourcing histories. Accordingly, the informants in these companies were in a good position to address the complexities of Turkey and other supplier countries. 
which source the goods they sell from independent contract manufacturers that are typically located in developing economies (Gereffi, 1994). Having moved manufacturing offshore, the buyers themselves primarily engage in the high valued-added activities of design, sales, and marketing, creating brands and images that shape mass-consumption patterns (Dicken and Hassler, 2000; Gereffi, 1999).

Notwithstanding the seemingly subordinate position of local firms in the value chain, the GVC framework does not construe local firms as passive agents who merely get locked into the role of manufacturer. Instead, it recognizes the possibility for a progression to more complex roles. Gereffi $(1999,2005)$ defines these trajectories as a form of industrial upgrading. In most export-oriented industries, the typical path to industrial upgrading involves a transition from assembly to full-package exports. Assembly exports involve the labor-intensive assembly and reexport of simple manufactured goods from imported inputs, whereas full-package exports involve the making of finished consumer goods by contract manufacturers in locally owned factories. Accordingly, full-package manufacturers develop the capability to interpret designs, make samples, source the needed inputs, monitor product quality, meet the buyer's price, and guarantee on-time delivery. They may also develop the capability to meet a wide range of social and environmental standards if they work with lead firms that adopt a corporate code of conduct (Gereffi et al, 2001).

Applications of the GVC analysis to date have emphasized three strategies by which full-package exporters may sustain their competitiveness. The first strategy is the creation of backward linkages in the domestic economy. Backward linkages are essential to retaining a competitive edge because full-package suppliers are expected to develop reliable sources of supply (Gereffi et al, 2005). A second strategy is the creation of cross-border triangle manufacturing arrangements, in which full-package suppliers relocate production to geographically and culturally proximate countries (Gereffi and Pan, 1994). Historically, the primary motivation behind these arrangements has been cost or quota considerations (Gereffi and Memodovic, 2003).

A third strategy is to reduce dependence on foreign buyers by developing 'originalbrand manufacturing' capabilities. The GVC perspective anticipates that full-package suppliers may eventually develop these capabilities because, in interacting with foreign buyers, suppliers learn about not only upstream but also downstream segments of the chain. In this connection, original-brand manufacturing also corresponds to the most complex export role that can be attained by suppliers because it involves the high value-added activities of marketing and sales of own-branded products. Unlike the transition from assembly to full-package, the transition from full-package to originalbrand manufacturing can be difficult because of complex barriers to entry (for example, Humphrey and Schmitz, 2001; Schmitz and Knorringa, 2000).

\section{The broader institutional context and sustained competitiveness}

Given its analytic focus on the value chain and on the role of lead firms therein, the GVC perspective stands in stark contrast to approaches that look for the sources of competitiveness in the broader institutional setting. Although the GVC perspective does not entirely neglect this context, it adopts a narrower view of it, emphasizing mostly its international dimension. In this regard, it highlights how trade regulationssuch as the MFA, or regional integration schemes, such as the North American Free Trade Agreement and the European Union (EU) - facilitate or hinder the insertion of new actors in value chains (for example, Bair, 2002; Begg et al 2003). The emphasis on the international dimension is actually quite well established, as much of the GVC literature has focused on buyer-driven chains, particularly apparel, in which trade has historically been subject to international regulations (Rothstein, 2005, page 53). 
Although recognizing the utility of the insights of the GVC perspective, recent literature on industrial upgrading has taken issue with this one-dimensional conceptualization and pointed to the multilayered context in which upgrading occurs (Cutrini, 2003). Accordingly, this literature proposes to incorporate into GVC analysis a fuller discussion of institutional processes - one that takes into account both the international and the national levels. ${ }^{(3)}$ Recent studies of the apparel industry in transition economies examine how, along with the global dynamics prescribed by the GVC framework, such variables as national legal requirements, legacies of state socialism, and postsocialist regulatory regimes shape firm strategies and thereby upgrade outcomes (Pickles, 2002; Smith et al, 2003; 2004). In a related effort, studies of other industries illustrate how government policies and interventions by local authorities may be linked with firms' decisions to upgrade (Czaban and Henderson, 2003; Dolan and Tawari, 2001; Rothstein, 2005).

Although it acknowledges the relationship between global economic processes and industrial upgrading, this literature is reluctant to base causality solely on chain dynamics. Attention is on national institutional processes, which may interfere with chain dynamics by providing resources (or obstacles) that facilitate (or hinder) efforts of local firms to respond to competitive pressures. When the context is broadened to include the national scene, however, analysis needs to consider the capacity of additional actors, such as the state and business associations, which are present in all national economies in varying degrees (Hollingsworth et al, 1994, pages 5-8). Tying this in with the concerns of Smith et al (2004), we argue that these actors, when present, can facilitate or hinder the adjustment of local firms to competitive pressures generated by global buyers.

How is it that Turkey has emerged and remained competitive as a leading fullpackage supplier of apparel? We outline below how Turkey's rise and continued success as a full-package supplier can best be understood as a multilayered process, in which international regulations, regional integration schemes, domestic producers, and global buyers have played key roles. In the Turkish apparel industry, the majority of firms have become full-package suppliers, establishing this role as Turkey's main export niche. These processes have unfolded in a distinct national context, however, in which industry associations and the state have been influential.

\section{The rise of the Turkish apparel industry: international regulations, global buyers, and Turkish textiles}

The initial boost to Turkish exports was given in the early 1980s, when Turkey followed the East Asian example and switched from import-substituting industrialization to an outwardly oriented, export-led growth strategy. Apparel immediately became the leading sector that the economy relied on for export growth. As highlighted in table 2, Turkey's apparel exports went up from an insignificant US $\$ 1.3$ billion in 1985 to US $\$ 11.2$ billion in 2004. Throughout this period, Turkey continued to rely on apparel as a leading export sector. International trade policies and regulations, coupled with the growing demand from global buyers, have played pivotal roles in this process.

At the international level, Turkey's long-standing association with the EU is a key variable that facilitated Turkey's inclusion in the global apparel value chain. Specifically, this association granted Turkey preferential access to one of the largest apparel markets in the world. Having preferential access, in turn, was important because of the international restrictions that historically applied to textiles and apparel trade, first under the MFA in 1974-94, and later under the World Trade Organization's Agreement

(3) Geographers also emphasize subnational levels, such as 'industrial clusters' (for example, Humphrey and Schmitz, 2002), but an analysis of this level is beyond the scope of this paper. 
on Textiles and Clothing, which was phased in during a ten-year period, 1995-2004 (Gereffi and Memodovic, 2003).

Under this restrictive trade environment, both the United States and the EU implemented trade regimes that resulted in a complex, multilayered hierarchy of preferences that greatly determined the degree of access to their markets. Since 1963, Turkey has enjoyed the status of 'preferential supplier' in the EU market. Consequently, instead of the MFA, Turkey's textile and apparel trade with the EU was governed by a series of voluntary restraint agreements that helped to determine quota levels (Bodgener, 1997). Turkey consolidated its special status in the EU with the establishment of a Customs Union in 1996, which removed all of the existing restrictions. The Customs Union also gave Turkey access to the countries in the European periphery; after 1996, Turkey signed a series of free-trade agreements with these countries in order to align itself to the EU's preferential trade regime. At the beginning of 1996, quantitative restrictions on textile products originating in Central and Eastern European and in some Mediterranean countries were abolished. In reciprocation, these same countries offered liberalized access to Turkish manufacturers.

In complete contrast, Turkish textile and apparel exports were restricted in the United States, which imposed quotas on imports of textiles and apparel from Turkey under a bilateral agreement in 1987. Moreover, the United States denied Turkey preferential duty treatment under its trade system. As a result, until the MFA quota phaseout in 2005, Turkey remained at the bottom of the US hierarchy of preferences.

Despite some decline in their trade over the years, the EU is still Turkey's major trading partner in textiles and apparel. In 1990 the EU-12 took 80\% of Turkey's exports, whereas in 2005 the EU-15 took 76\%. The United States, by far the world's largest importer of apparel, received only $8 \%$ to $16 \%$ of Turkey's apparel exports during the $1985-2000$ period. By 2005 the US share in Turkey's total apparel exports had dropped to $8 \%$, down from $16 \%$ in 2000 . The EU member states Germany, United Kingdom, France, and the Netherlands were the most important destinations for Turkish apparel exports from 1985 to 2005 (see table 2). Germany has been Turkey's major trading partner, absorbing more than 50\% of apparel exports until the mid-1990s. Notwithstanding a decrease in its share, starting in the early 2000s, Germany continues to be the primary destination for Turkish apparel exports.

A common feature of Turkey's main export markets is that their apparel industries have a long history of global production and sourcing. The German apparel industry began to internationalize as early as the 1960s, when apparel manufacturers began to relocate production to nearby low-cost countries (Hurcks, 1994). It was not until the 1980 s, however, that the pace of internationalization in the German apparel industry really began to increase, as a result of the rising cost of German labor. In 1982, $77 \%$ of all apparel production was carried out in Germany; after a decade this ratio had dropped to about 24\% (Tücking, 1999, page 178). Similar developments have been observed in the United Kingdom, France, and the Netherlands (Scheffer, 1995). By the time Turkey had turned to an export-oriented growth strategy in the 1980s, there was growing demand in international markets and this demand increased even more in the following decade.

It was not only manufacturers, however, but also wholesalers and different types of retailers that began to source from overseas. Thanks to greater consolidation in the retail sector, during the 1980s some retail groups in Europe developed the capability to seek out and work with foreign suppliers, mainly from East Asia. This practice of global sourcing became even more widespread in the $1990 \mathrm{~s}$, as retailers continued to consolidate and their private-label merchandise (or store brands) gained ground (Fernie, 1992; Robinson et al, 2000; Scheffer, 1995; Wortmann, 2003). In order to source 
Table 2. Turkey's major trading partners in apparel: 1985-2004 (US \$ thousand) (source: 1985-2000 World Trade Analyzer, 2005 United Nations Comtrade data).

\begin{tabular}{|c|c|c|c|c|c|c|c|c|c|c|c|c|c|c|}
\hline 1985 & Value & $\%$ & 1990 & Value & $\%$ & 1995 & Value & $\%$ & 2000 & Value & $\%$ & 2005 & Value & $\%$ \\
\hline \multicolumn{15}{|c|}{ Export destinations } \\
\hline Germany & 634898 & 50 & Germany & 1783578 & 53 & Germany & 3031603 & 47 & Germany & 2701158 & 39 & Germany & 3159190 & 27 \\
\hline UK & 195208 & 15 & France & 337387 & 10 & US & 646063 & 10 & US & 1105984 & 16 & UK & 2031370 & 17 \\
\hline US & 98912 & 8 & US & 317087 & 9 & France & 444650 & 7 & UK & 858466 & 12 & US & 947033 & 8 \\
\hline France & 67546 & 5 & $\mathrm{UK}$ & 246072 & 7 & Netherlands & 348002 & 5 & France & 579246 & 8 & France & 585474 & 5 \\
\hline Iraq & 53025 & 4 & Netherlands & 133281 & 4 & UK & 340415 & 5 & Netherlands & 404022 & 6 & Netherlands & 811214 & 7 \\
\hline EU-10 & 985830 & 78 & EU-12 & 2687129 & 80 & EU-15 & 4689012 & 73 & EU-15 & 5413009 & 77 & EU-15 & 8938782 & 76 \\
\hline Total & 1267639 & & Total & 3370286 & & Total & 6428175 & & Total & 6985453 & & Total & 11833106 & \\
\hline \multicolumn{15}{|c|}{ Import countries } \\
\hline Germany & 1736 & 30 & Germany & 10436 & 33 & Italy & 25296 & 27 & Italy & 73922 & 20 & China & 182910 & 23 \\
\hline UK & 1442 & 25 & Italy & 6606 & 21 & Germany & 17292 & 19 & UK & 52804 & 15 & Italy & 94956 & 12 \\
\hline Cyprus & 749 & 13 & UK & 4794 & 15 & UK & 12737 & 14 & China & 31818 & 9 & India & 44025 & 6 \\
\hline Italy & 641 & 11 & France & 3056 & 10 & France & 12023 & 13 & Germany & 31127 & 9 & Bangladesh & 39783 & 5 \\
\hline Switzerland & 525 & 9 & Hong Kong & 1157 & 4 & Netherlands & 8395 & 9 & Turkmenistan & 27903 & 8 & Malaysia & 39736 & 5 \\
\hline EU-10 & 4178 & 73 & EU-12 & 27724 & 88 & EU-15 & 79529 & 86 & EU-15 & 243816 & 67 & EU-15 & 219109 & 28 \\
\hline Total & 5692 & & Total & 31684 & & Total & 92455 & & Total & 363607 & & Total & 787841 & \\
\hline
\end{tabular}

Note. Total indicates the total for the respective commodities. \% indicates country's share in that total. 
private-label products, these retailers began to bypass local manufacturers, forming direct ties with suppliers (Terrahe, 1997).

From a GVC perspective, the major implication of this rising international demand was that Turkey could link up with diverse sets of foreign buyers. First, some of these retailers, such as the German department store Karstadt, began arriving in Turkey in the early 1980s to set up full-package networks. Turkey entered the 1990s with ties to a wide spectrum of European buyers, principally based in Germany. Indeed, in the mid-1990s, the most frequently cited buyer category was retailers, which included department stores, such as Karstadt, Hertie, Kaufhof, and Printemps, mail-order companies, such as Otto, Neckermann, Baur, and Bader, and other specialty chains, such as H\&M, C\&A, Peek und Cloppenburg, Mexx, and s. Oliver. It was not uncommon for manufacturers to link up also with independent retailers or 'boutiques'.

A second group of buyers consisted of brand-name companies. These ranged from global firms, such as Adidas, which focused more on design and marketing, to highend fashion companies, such as Hugo Boss, which combined manufacturing with design and marketing. Other brand-name manufacturers, such as Mustang and H.I.S., focused on standardized products and were better known regionally. ${ }^{(4)}$ Third, some manufacturers worked with wholesalers and importers (Neidik, 2004a). All of these buyers have continued to be important for Turkey into the 2000s, but they had been joined by a number of other global players over the years. Some of the most notable cases have been the marketers Puma and Nike, and the retailers Marks and Spencer, Next, and The Gap.

The growing demand by foreign buyers for full-package production was evident in the 1990s. The establishment of buying offices in Turkey provides solid evidence in this regard. Buying offices are typically set up in countries that retailers source from in large quantities. ${ }^{(5)}$. Indeed, in the early 2000s, some of the retailers-such as the department store Karstadt, the specialty retailer C\&A, the mail-order companies Otto and Neckermann, and the branded manufacturer Gerry Weber-operated buying offices in Turkey. A few retailers and brand-name companies have taken this concept a step further by establishing regional offices in Turkey, through which they coordinate their entire sourcing operations in the Middle East, North Africa, and/or Eastern Europe. A prominent example of these companies is The Gap Inc. Other buyers, which also source from these regions, but in much smaller quantities, choose to work with independent Turkish buying agencies. Just like buying offices, these agencies help foreign buyers coordinate their sourcing on a regional basis. The Limited Brands, for instance, works with such an agency.

As predicted by the GVC perspective, the growing role of global buyers, coupled with Turkey's preferential trade arrangements in Europe, facilitated the insertion of the Turkish apparel industry into GVCs. There was, however, one other factor that further stimulated the rise of Turkey as a full-package supplier. This was the availability of a national industrial infrastructure, which can be linked to government policies that preceded the trade liberalization of the 1980s.

Indeed, when Turkey turned to apparel production in the 1980s, it primarily benefited from an industrial infrastructure that had been in the making for the past few decades. Of primary importance was the existence of a versatile textile sector. ${ }^{(6)}$

(4) H.I.S. was acquired by the US-based VF Corporation in 2000.

${ }^{(5)}$ Buying offices are important mechanisms in buyer-driven value chains because they enable tacit information exchange between buyers and suppliers by facilitating frequent and intense interaction (Gereffi et al, 2005, page 92).

(6) In this regard, Turkey presents a striking contrast to Mexico, a rising full-package supplier in which the textile sector was far weaker (Bair and Gereffi, 2001). 
Turkey's textile producers had been one of the major beneficiaries of the economic regimes pursued during the three decades that preceded the trade liberalization of the 1980s. Before the 1950s Turkey went through a period of etatism, which resulted in the creation of state-owned enterprises in several sectors. Textiles were no exception. This began to change in the 1950s when private capital stepped up its investment in textiles, thanks to incentives provided by the government. These investments continued during the import-substituting industrialization period of $1960-80$, as the state strengthened autonomous private-sector activity through import-tax exceptions, tariff and tax deductions on capital goods, low-cost credit and investment allowances.

The textile sector was favored by both the government and private capital because of the availability of raw materials in Turkey for the production of natural and synthetic fibers. From an economic point of view, a strong textile sector could add value to Turkey's high-quality cotton crop. Additionally, it created jobs for Turkey's already large and growing economy. The sector was attractive from an entrepreneurial vantage point as well, thanks to the relatively low barriers to entry compared with more technology-intensive sectors. Consequently, the production share of the private sector in cotton textiles rose from about $23 \%$ in 1950 to $70 \%$ in 1962 and to $77 \%$ in 1972 (Yaşar, 1996, pages 53-57). Turkey began to export a small portion of its textiles for the first time in the 1970s, mostly in the form of cotton yarn and fabrics.

When Turkey turned to an export-oriented strategy in the 1980s, there was already an industrial base in place that the apparel sector could benefit from. More importantly, unlike some other sectors in the economy that were exclusively dominated by state-owned enterprises, there was private capital with the necessary industrial and managerial skills to help Turkey add further value to its textiles by extending production into apparel manufacturing. As a result, some of the largest full-package apparel suppliers in Turkey have emanated from textile firms. These companies typically have not invested in higher value-added design and marketing activities because textile production remains their core business. The most prominent cases combine their traditional textile and apparel operations with the production of home and/or technical textiles. Some of these textile firms have even launched brands for home textiles and expanded into retailing textiles in their own stores.

\section{Further growth of Turkey as a full-package supplier: the competitive strategies of Turkey's firms in the 1990s and 2000s}

In order to sustain competitiveness as full-package suppliers in the 1990s, Turkish firms had to meet a range of requirements regarding price, quality, delivery, and labor standards. Turkey had already begun to face price competition from other fullpackage countries, such as China and India. As of 1994 hourly wages in Turkey were US \$2.31, compared with US \$0.48 in China and US \$0.58 in India. By 1998 the rate for Turkey was US\$2.48, compared with US $\$ 0.62$ in China and US $\$ 0.60$ in India (Werner International, 1998).

Given its relatively high wage rates, the sustainability of Turkey's position as an international supplier would depend, at a minimum, on meeting the rest of the requirements. Indeed, interviews with lead firms suggest that, in the 1990s, quality and lead times were Turkey's chief advantages vis-à-vis its competitors. These strengths largely compensated for Turkey's higher labor costs. The mail-order company, Baur, for example, explained it this way:

"Turkey is a country where you place repeat orders. We have two seasons a year and they are planned one year before the season starts. We place our initial orders, e.g. a cotton T-shirt, 2,000-5,000 pieces of it, with the Far East. Once the catalogue is issued, we check out the response of the customer. If this shirt is selling well, then 
we place repeat orders. I may place a repeat order of 5,000 with Turkey for shorter production times .... Quality is also good .... They get the measurements and do samples and quality control. They're quite good. You don't have to go back and forth to tell them this is wrong, do that again .... But we won't place the initial orders with Turkey because the Far East is cheaper" (interview with Korinna Landwehr, Import Manager, Baur, Germany, 25 July 1996).

By the 2000s lead firms were citing similar reasons as the source of Turkey's competitiveness as a full-package supplier. When asked what factors in general played the key role in determining their supplier base, these firms would emphasize that it was usually a combination of price, technical capabilities, speed of response, and quality. Some retailers and manufacturers also emphasized the ability of suppliers to fulfil social and environmental standards (Neidik, 2004a). For Turkey, however, quality consideration came to the fore. According to Siso Textil, the parent company of the German discount specialty chain Minitextil:

"Turkey is an important country that offers creativity .... We always consider niche specialization. What country offers what? ... For us, fit precision is an important theme. For instance, Turkey and Spain can meet these requirements. These are countries that offer quality" (interview with Christoph Bettag, president, and Claus Nürnberg, sourcing director, Siso Textil, Germany, 27 July 2000).

Turkish firms have developed a number of strategies in order to maintain their competitive edge in full-package production. Some firms sought to integrate the production process vertically in order to meet the requirements for quality, on-time delivery, and labor standards better. Other firms established international triangle manufacturing arrangements in order to take advantage of cost and quota advantages offered by neighboring countries. Last but not least, a few full-package suppliers supplemented their full-package business with original-brand manufacturing. We will discuss each of these strategies in turn.

\section{Developing backward linkages}

A key strategy employed by Turkey's full-package apparel manufacturers has been to develop reliable sources of textile supply. Some full-package manufacturers began to invest in integrated factories in the 1990s. In the Turkish case, integration consisted of two components. First and foremost, manufacturers wanted to add fabric manufacturing to their in-house capabilities. Second, they wanted to reduce their dependence on subcontractors. Indeed, when apparel firms first began to form in the 1980s, they carried out most of their production in small workshops, in conjunction with a large number of subcontractors. This began to change in the 1990s, when firms began to pool a whole range of production steps from knitting to delivery in integrated factories (Neidik, 2004b).

Several main reasons were cited for these investments in the 1990s. First and foremost, manufacturers desired to secure a continuous supply of fabrics. Notwithstanding the availability of a wide range of domestic textiles, they preferred to knit and/or weave their own fabrics, primarily to shorten lead times. Second, manufacturers wanted to exercise more control over quality as it was difficult to maintain consistent quality when one worked with many independent subcontractors. Third, they wanted to increase production capacity in order to attract buyers who placed larger orders and offered better prices.

These developments did not result in a domestic supply chain whereby production is carried out exclusively in integrated apparel factories. Subcontracting is still widespread and arrangements are often unregistered (SOMO, 2003, page 3). Manufacturers have tried to exert more control over their subcontractors. For instance, in 1996, 
one manufacturer reported that only $20 \%$ of its production was sewn in its own factory. The rest was subcontracted to thirteen to fifteen specialized workshops. As of 2001, however, the same manufacturer had set up another factory and reported working with only four subcontractors (interviews with M Hakan Ayaşlığlu, general manager, Tayeks, Turkey, 12 June 1996 and 1 July 2001). These subcontractors worked exclusively for the manufacturer and were subject to constant scrutiny by the manufacturer's technician. ${ }^{(7)}$

By the 2000s in-house production became even more important for full-package suppliers. In addition to quality concerns, suppliers began to face pressures to comply with a wide range of labor and environmental standards that were being imposed on them by global corporations. Full-package manufacturers in Turkey have been under increasing pressure to incorporate these standards into their production processes since the late 1990s. As noted by one manufacturer:

"We have been undergoing these audits for the past 3 years .... They even want to inspect subcontractors .... It is hard to do business with Reebok, for instance. They have this human rights department. They come and see that there is no union in the factory. They argued that if there is no union, you have to select worker representatives. We had to institute new rules to accommodate such requests" (interview with M Hakan Ayaşlığlu, 1 July 2001).

Apparel firms continue to subcontract labor-intensive stages to bring down labor costs or create additional capacity in times of high demand. Many Turkish full-package suppliers have created dense domestic subcontracting networks to complement their integrated export-oriented factories. Furthermore, a number of apparel companies have extended their supply chain to encompass textile manufacturing, alongside those textile firms that branched into apparel manufacturing.

\section{Cross-border production networks}

A second strategy employed by full-package suppliers has been to set up triangle manufacturing arrangements in the neighboring countries of Europe and Asia. Although this strategy became more visible in the early 2000s, Turkish expansion in the European periphery can be traced back to the early 1990s. One of the first examples of this expansion was the investments made by the integrated manufacturer Güneydoğu, which formed a joint venture in 1993 with the European Bank of Reconstruction and Development and the Turkmenistan government to set up plants in Turkmenistan. Today, Güneydoğu owns numerous plants in the area and exports apparel from these locations primarily to the United States, where the main buyers are companies such as Wal-Mart, Sara Lee, and the VF Corporation. Another example of a textile company that invested in Central Asia is the textiles manufacturer Bursel Holding, which owns twelve plants in Uzbekistan, in partnerships with Mitsubishi and the Uzbekistan government (DEIK, 2003a). A similar case is the integrated textiles company Yeşim, one of Turkey's top exporters. Yeşim owns three manufacturing plants in the Turkic Gagauzia Region of Moldova and is currently undertaking new investments.

This cross-border production strategy picked up towards the end of the 1990s and a new relocation pattern began to crystalize in the 2000s as Turkey's apparel and textile manufacturers started to invest more extensively in production sites in Eastern Europe.

(7) As most subcontracting arrangements in Turkey are unregistered, there are no reliable data to document the exact scale of this phenomenon. This information has become especially difficult to obtain in recent years because, even when arrangements are registered, the use of subcontractors can be in violation of the labor and environmental standards imposed by some foreign buyers, such as Nike. 
The process was facilitated by the free-trade agreements that Turkey had to sign with many of these countries after joining the Customs Union in 1996.

Two countries stand out in Eastern Europe as relocation targets. The country that attracted most of the investments was Romania (DEIK, 2003b). Romania has been followed by Bulgaria, which adjoins Turkey and is home to a large Turkish ethnic minority (DEIK, 2004). Although the exact scale of these triangle manufacturing arrangements is unknown, they have taken two main forms. In some cases Turkish firms took advantage of the ongoing privatization in Eastern Europe and acquired apparel and textile factories there. Other Turkish companies have followed another strategy, in which they use only East European subcontractors. This has been especially common in Bulgaria, which borders the Thrace region of Turkey, where most of Turkey's apparel manufacturing is concentrated (SOMO, 2003).

The reasons behind this relocation were twofold. First, these sites offered abundant low-cost and skilled labor. The second and more important reason was quota restrictions. As discussed above, Turkish apparel firms restructured their supply chains during the 1990s to increase capacity, improve quality, and shorten lead times. Equipped with an improved organizational infrastructure and plenty of export expertise, they found themselves in a better position to export to the United States. The US market was an attractive alternative to the EU market because of its domination by large buyers. These corporations placed significantly bigger orders, compared with the more volatile and smaller orders of their European counterparts.

In the late 1990s Turkish firms began to look for ways to increase their exports to the United States and to decrease their dependence on the EU in order to diversify their export markets. But Turkey's apparel exports to the United States were subject to quota restrictions. To overcome this barrier, Turkish manufacturers began to shift production to neighboring countries, which, despite being similarly subject to US quotas, were unable to fulfil them. In this connection, it is not surprising that Turkish manufacturers also made investments in the Qualified Industrial Zones of Jordan and formed joint ventures with companies from Israel. Both of these countries had free-trade agreements with the United States, and hence offered quota-free access to the US market.

\section{Own-brand manufacturing}

A third strategy of Turkey's full-package suppliers involved downstream investments (Tokatlı, 2003; Tokatlı and Kızılgün, 2004). These suppliers pushed beyond the fullpackage role by integrating their manufacturing expertise with the design and sales of their own-branded products, both at home and overseas. In terms of brand development, the most successful firms have been manufacturers of jeans and men's outerwear. One of the most prominent examples is the Turkish jeans manufacturer Erak, a company that has served as a full-package supplier to several EU-based and US-based companies for more than a decade before launching its own brand of 'Mavi' jeans (for a detailed discussion see Tokatlı and Kızılgün, 2004).

However, the number of full-package suppliers who have made this transition is limited. None of the branded manufacturers have entirely abandoned the role of full-package supplier in favor of original-design and original-brand manufacturing. Even Erak, the manufacturer of the internationally renowned Mavi brand, continues to supplement its brand business with full-package exports (Tokatlı and Kızılgün, 2004). Furthermore, the share of original-brand manufacturing in total exports remains fairly small. As of 2002, Erak ranked 58th among the top-1000 exporters in Turkey, with a total export value of about US $\$ 90$ million, according to a survey carried out by the Turkish Exporters Assembly (Türkiye İhracatçllar Meclisi website, http://www.tim.org.tr). 
The combined value for Erak's full-package and original-brand exports accounted for only about $1.1 \%$ of Turkey's total apparel exports in 2002, underscoring the limited role this type of export plays in Turkey's apparel trade.

In summary, the key developments that unfolded in the Turkish apparel industry in the 1990s and early 2000s are consistent with the main features of the buyerdriven model in the GVC perspective. These developments do not by themselves, however, fully account for how Turkey has sustained its competitive export edge. For a more thorough understanding of the sources of competitiveness in the Turkish case, a closer look is needed at a key set of institutional actors which have supplemented the efforts by Turkish textile and apparel firms to improve the country's international competitiveness. It is to this analysis that we now turn.

\section{Business associations and the state in textiles and apparel}

Two key actors in the Turkish national context have affected the competitiveness of full-package apparel suppliers. The first group of actors are business associations, which have offered a wide array of support services to their members and acted as pressure groups at both national and international levels. The second actor is the state, which devised various policies to enhance the competitiveness of local firms, although some of these policies have been controversial in the Turkish context.

As noted above, private capital played a key role in the early development of Turkey's textile and apparel sectors. This was beneficial for the industry in the long run because it facilitated the formation of business associations with the lobbying power to influence domestic and international policy. Indeed, one of the oldest civil-society organizations in Turkey, the Turkish Clothing Manufacturers Association (Türkiye Giyim Sanayicileri Derneği, TGSD), was established by apparel manufacturers in the mid-1970s. Although TGSD still represents a relatively small proportion of firms, it is perceived by Turkish apparel firms to be the most prestigious business network in the industry (Riddle and Gillespie, 2003).

A key function of TGSD has been the promotion of the Turkish apparel sector in the international arena. This has been done in a couple of ways. First, TGSD has encouraged the participation of member firms in international trade fairs since 1979. These fairs were the primary method of active marketing through which Turkish firms and their products gained international visibility and recognition. In the 1990s TGSD started a tradition of hosting fashion fairs in Istanbul. TGSD also represented the industry in international associations, such as the European Apparel and Textile Organization (Euratex) and the International Apparel Federation.

An even more significant function of the association is lobbying. TGSD constantly strives to shape government and EU policies, both at home and overseas. In the early 2000s, for instance, TGSD lobbied for legislation that would give incentives to exporters to increase investments in Anatolia (a large heartland province in Turkey) rather than abroad. Notwithstanding modifications to the original proposal, this legislation was passed in 2004. In a more recent effort, TGSD lobbied, in anticipation of post-MFA competition, for the implementation of safeguard measures against China, both domestically and internationally. At home the association played the lead role in forming a joint initiative that mobilized several interest groups to convince the Turkish government to impose an annual limit to anticipated increases in Chinese imports in the post-MFA period. This initiative was successful, and it convinced the government to impose quotas on forty-two product categories for the next three years. Abroad, TGSD lobbied with fellow Euratex members to pressure the European Commission to implement safeguard measures against China. 
The efforts of TGSD have been further supplemented by the efforts of the Istanbul Textile and Clothing Exporters Association (ITKIB). Unlike TGSD, ITKIB is a semiautonomous, governmental organization that requires export-oriented firms to register with one of the four associations operating under its roof. ITKIB, which was founded in 1986, provides a wide array of services for exporters. During the MFA period, a main function of ITKIB was to negotiate for EU quotas. One of ITKIB's current roles includes the provision of financial support to exporters wishing to participate in trade fairs. The association is also a significant source of export information for member apparel firms, especially ones that are new ventures (Riddle and Gillespie, 2003).

ITKIB is one of the most supportive institutions for the apparel industry, but it is not the only one. Another significant group of actors in Turkey are export trading companies (ETCs). Since the 1980s there have been several attempts by the state to promote the formation of ETCs in Turkey. ETCs are formed when firms come together to get better financing, improve market access, and boost export performance-in other words, to alleviate problems that are commonly observed in small-firm sectors such as apparel. The early ETCs in Turkey were formed as the export arms of large Turkish industrial and business groups. Although these ETCs usually gave priority to their parent companies and affiliates, they also worked with smaller domestic manufacturers. The number of companies that achieved ETC status was 23 in 1990. The average number of domestic suppliers per ETC was about 76 in 1992; this number varied from 5 to 255 for individual ETCs (Dicle and Dicle, 1992, pages 64-65). Currently, there are 53 ETCs in Turkey and at least 17 of these specialize in apparel and textiles trade (Undersecretariat of Foreign Trade, 2005, http://www.dtm.gov.tr/lHR/ dtss/Karar2005.doc).

In recent years, legislative modifications have been made to promote the formation of ETCs further. Although most ETCs remain affiliated with prominent business groups, there are industry-specific variants, which account for a significant portion of Turkey's textiles and apparel exports. Hedef, founded by 44 textile and apparel exporters in 1999, is a prominent example. The company now has over 200 members and it is one of the largest exporters in the sector, with an export value of US \$619 million in 2004 (Hedef website, http://www.hedefdis.com.tr).

Not all state policies, however, have benefited the sector. Particularly deleterious are the investment incentives that were given to the apparel sector in the mid-1990s, which were implemented as part of a larger program involving other sectors. Coupled with the anticipated positive impact of the pending Customs Union, the incentives encouraged a large amount of investment in apparel (Bodgener, 1997; Evgeniev, 2005). Nonetheless, this program has also been criticized for not having a strategic direction. As noted by a representative of Teksif, the Textil and Garment Workers' Union:

"There has been no government policy targeting the sector ... many incentives were given and [entrepreneurs] invested in the sector, but not in the right areasareas where there was actually a need for new investments. It had almost become fashionable to invest in garments and textiles, so that's what everybody did in the 1990s. Government did not help channel these investments in the right direction, causing inflation in investments" (interview with Engin Sedat Kaya, research coordinator, Teksif, Turkey, 22 August 2005).

In addition, the state is often criticized for disregarding regional differences and implementing a flat rate for minimum wage, demanding high social security premiums and taxes from registered employers, and not being able to bring down energy prices. All interest groups, including business associations and unions, argue that these policies will hurt the labor-intensive, cost-sensitive apparel sector in the post-MFA period. 
Table 3. Types of exporting firms in the Turkish apparel industry (source: authors' own elaboration based on interview and archival data).

\begin{tabular}{|c|c|c|c|c|c|c|c|c|}
\hline \multirow[t]{2}{*}{ Type of firm } & \multicolumn{2}{|c|}{ Value chain segments } & \multirow{2}{*}{$\frac{\text { Market }}{\text { brands }}$} & \multirow{2}{*}{$\begin{array}{l}\text { Main } \\
\text { retail }\end{array}$} & \multirow{2}{*}{$\begin{array}{l}\text { Temporal } \\
\text { orientation }\end{array}$} & \multirow{2}{*}{$\begin{array}{l}\text { Examples of } \\
\text { clients }\end{array}$} & \multirow{2}{*}{ origin $^{a}$} & \multirow{2}{*}{ representative firms } \\
\hline & fabrics & apparel & & & & & & \\
\hline Textiles only & yes & no & sometimes & sometimes & $\begin{array}{l}\text { exports and } \\
\text { domestic }^{\mathrm{b}}\end{array}$ & $\begin{array}{l}\text { textile } \\
\text { companies } \\
\text { from EU, USA }\end{array}$ & pre-1980s & $\begin{array}{l}\text { İsko, Zorlu, } \\
\text { Orta Anadolu, } \\
\text { Abalıoğlu, } \\
\text { Küçükçalık }\end{array}$ \\
\hline $\begin{array}{l}\text { Integrated } \\
\text { textile firms }\end{array}$ & yes & yes & sometimes & sometimes & $\begin{array}{l}\text { exports and } \\
\text { domestic }\end{array}$ & $\begin{array}{l}\text { branded manufacturers, } \\
\text { marketers, and } \\
\text { retailers from } \\
\text { EU, USA }\end{array}$ & pre-1980s & $\begin{array}{l}\text { Bossa, Yeşim, } \\
\text { Altınyıldı, } \\
\text { Güneydoğu, } \\
\text { Güney-Polgat }\end{array}$ \\
\hline Full-package & sometimes & yes & no & no & $\begin{array}{l}\text { mostly } \\
\text { exports }\end{array}$ & $\begin{array}{l}\text { branded manufacturers, } \\
\text { marketers, and } \\
\text { retailers from } \\
\text { EU, USA }\end{array}$ & mid-1980s & $\begin{array}{l}\text { Tay Group, } \\
\text { Arat, Gals } \\
\text { Tekstil, Seda } \\
\text { Giyim }\end{array}$ \\
\hline Branded & sometimes & yes & yes & sometimes & $\begin{array}{l}\text { mostly } \\
\text { exports, } \\
\text { some } \\
\text { domestic }\end{array}$ & $\begin{array}{l}\text { branded manufacturers, } \\
\text { marketers, and } \\
\text { retailers from } \\
\text { EU, USA }\end{array}$ & early 1990 s & $\begin{array}{l}\text { Erak, Eroğlu, } \\
\text { Sarar, Sun } \\
\text { Tekstil, Öztay }\end{array}$ \\
\hline Subcontractors & no & yes & no & no & $\begin{array}{l}\text { domestic but } \\
\text { as indirect } \\
\text { suppliers of } \\
\text { export-oriented } \\
\text { larger firms }\end{array}$ & $\begin{array}{l}\text { larger export-oriented } \\
\text { domestic } \\
\text { manufacturers }\end{array}$ & $\begin{array}{l}\text { always present, } \\
\text { but intensifies } \\
\text { in the } 1990 \mathrm{~s}\end{array}$ & various \\
\hline $\begin{array}{l}\text { Trading } \\
\text { companies }\end{array}$ & sometimes & yes & planned & no & exports & $\begin{array}{l}\text { branded manufacturers, } \\
\text { marketers, and } \\
\text { retailers from } \\
\text { EU, USA }\end{array}$ & mid-1980s & $\begin{array}{l}\text { Ak-Pa, Bilkont, } \\
\text { Korteks, } \\
\text { Küçükçalık, } \\
\text { Hedef, GISAD }\end{array}$ \\
\hline
\end{tabular}


An important consequence of these policies so far has been to encourage the informal sector, estimated to be particularly large in the Turkish apparel industry. Indeed, it is estimated that the textile and apparel sectors employ about 2.5 million workers, but only half a million of these are registered (Grand National Assembly of Turkey, 2001). There are ongoing efforts by TGSD and other interest groups in Turkey to limit the influence of these government policies.

Overall, Turkey's rise and sustained competitiveness as a full-package supplier has resulted from a complex mix of international and national processes. As shown in table 3, Turkey's textile and apparel industry is made up of a diverse set of players. Integrated textile firms, full-package suppliers, branded suppliers, and ETCs all contribute to the full-package system, supported domestically by textile firms and a dense network of subcontractors. Although these firms occupy distinct value chain segments and hence have different capabilities, they serve similar types of global buyers. The variety of firms reflects the unique organizational ecology that has emerged in Turkey in response to international competitive pressures, the demands of global buyers, and the policies spearheaded by key institutional actors.

\section{Conclusion}

In this paper we have accounted for how Turkey emerged and sustained its success as a full-package apparel supplier during the past several decades by using insights from the GVC perspective as well as from its critics. The organizational changes taking place in key international markets created significant opportunities for Turkey in the 1980s. Coupled with Turkey's status as a preferential supplier to the EU, these opportunities enabled Turkey to forge links with a variety of lead firms that demanded full-package production in the global apparel value chain. Turkey's full-package suppliers developed a number of strategies to meet an increasingly demanding set of international conditions regarding price, quality, delivery, and labor standards. These strategies, however, were devised in a particular national context, in which key institutional actors have further shaped the competitiveness of Turkey's full-package model. Our analysis shows that, in the Turkish case, the efforts of full-package suppliers have been positively affected by domestic business associations. The role of the state, however, is more controversial. Whereas some policies have had a positive impact on the industry in the long run, other policies continue to pose obstacles.

Our study raises a couple of issues about the future of the Turkish apparel industry. The internationalization of Turkey's apparel and textile sectors through triangle manufacturing arrangements is an important development with future implications for both Turkey and Europe as a whole. By setting up these arrangements, Turkish firms have become key nodes in a regional value chain, linking a variety of global buyers with a tiered network of neighboring European suppliers. It is not clear whether triangle manufacturing will continue to be employed. A major driving force behind the expansion of Turkey's exports was the MFA quota restrictions. Given that these quotas were abolished by the World Trade Organization on 1 January 2005, will Turkish firms continue to expand in the European periphery in order to take advantage of wage differentials or will they abandon this strategy altogether?

A related question has to do with future upgrading opportunities for Turkish firms. Turkey's textile and apparel firms have been able to sustain their competitive edge in apparel exports as full-package suppliers with a growing emphasis on own-brand manufacturing, but increasing competition from countries such as China and India casts doubts on the further sustainability of this position. Will more firms be able to make the transition to branded manufacturing or will they lose out to China before they can develop higher value-added capabilities? 
For the time being, Turkey still has several advantages vis-à-vis its competitors. The predominance of regional buying offices in Turkey indicates that it is rapidly becoming an export hub for major global corporations. Coupled with its expertise in the fullpackage export role, Turkey is likely to sustain its competitive edge for the next several years. The future of the industry is suspect, however, unless specific steps are taken to promote upgrading to branded manufacturing among full-package suppliers and to consolidate further Turkey's potential as a production and sourcing bridge between Europe and Asia.

Acknowledgments. We would like to thank the three anonymous reviewers for their thoughtful comments and suggestions. Additionally, we are grateful to Evgeni Evgeniev for his helpful feedback on an earlier version of the paper. All remaining errors are our own.

\section{References}

Ateş A, 1999 Bugünden Yarınlara Tekstil ve Konfeksiyon Sektörü [The today and tomorrow of the Turkish textile and garment sector] (Teksif Sendikası, Ankara)

Bair J, 2002, "Beyond the maquila model? NAFTA and the Mexican apparel industry" Industry and Innovation $9203-225$

Bair J, Gereffi G, 2001, "Local clusters in global chains: the causes and consequences of export dynamism in Torreon's blue jeans industry" World Development 29 1885-1903

Begg B, Pickles J, Smith A, 2003, "Cutting it: European integration, trade regimes, and the reconfiguration of East-Central European apparel production” Environment and Planning A $352191-2207$

Bodgener J, 1997, "The clothing industry in Turkey" Textile Outlook International May, 37 - 59

Cheng L. Gereffi G, 1994, "US retailers and Asian garment production", in Global Production: The Apparel Industry in the Pacific Rim Eds E Bonacich, L Cheng, N Hamilton, P Ongs (Temple University Press, Philadelphia, PA) pp 63-79

Cruz-Moreira J, 2003 Industrial Upgrading nas cadeias produtivas globais: reflexões a partir das indústrias têxtil e do vestuário de Honduras e do Brasil [Industrial upgrading in global productive chains: reflections on the textile and apparel industries of Honduras and Brazil] PhD dissertation, Polytechnical School, University of São Paulo, http://www.teses.usp.br/ teses/disponiveis/3/3136/tde-03112003-142622/

Cutrini E, 2003, "Evolution of local systems in the context of enlargement",WP67, Sussex European Institute, University of Sussex, Falmer, Brighton, http://www.sussex.ac.uk/sei/documents/wp67.pdf

Czaban L, Henderson J, 2003, "Commodity chains, foreign investment and labour issues in Eastern Europe" Global Networks 3171 - 196

DEIK, Dış Ekonomik İlişkiler Kurumu (Foreign Economic Relations Board of Turkey, Istanbul) 2003a Özbekistan Ülke Raporu [Uzbekistan country report]

2003b Romanya Ülke Raporu [Romania country report] 2004 Bulgaristan Ülke Raporu [Bulgaria country report]

Dicken P, Hassler M, 2000, "Organizing the Indonesian clothing industry in the global economy: the role of business networks" Environment and Planning A 32 263-280

Dicle A, Dicle Ü, 1992,"Effects of government export policies on Turkish export trading companies" International Marketing Review $962-76$

Dolan C S, Tawari M, 2001, "From what we wear to what we eat: upgrading in global value chains", in The Value of Value Chains: Spreading the Gains from Globalisation Eds G Gereffi, R Kaplinsky (Institute of Development Studies, Sussex) pp 94-104

Evgeniev E, 2005 Shaping Development: National Light vs. Transnational Light Sector: Comparison of the Textile and Apparel Industry in Bulgaria and Turkey unpublished PhD dissertation, Department of Social and Political Science, Central European University, Budapest

Fernie J, 1992, "Distribution strategies of European retailers" European Journal of Marketing 2635 - 47

Gereffi G, 1994, "The organization of buyer-driven global commodity chains: how US retailers shape overseas production networks", in Commodity Chains and Global Capitalism Eds G Gereffi, M Korzeniewicz (Greenwood Press, Westport, CT) pp 95-122

Gereffi G, 1999, "International trade and industrial upgrading in the apparel commodity chain" Journal of International Economics 4837 - 70

Gereffi G, 2005, "The global economy: organization, governance, and development", in Handbook of Economic Sociology Eds N J Smelser, R Swedberg (Princeton University Press, Princeton, NJ and Russell Sage Foundation) pp 160-182 
Gereffi G, Kaplinsky R (Eds), 2001 "The value of value chains: spreading the gains from globalisation" IDS Bulletin 32 (special issue)

Gereffi G, Korzeniewicz M (Eds), 1994 Commodity Chains and Global Capitalism (Praeger, New York)

Gereffi G, Memodovic O, 2003 The Global Apparel Value Chain: What Prospects for Upgrading by Developing Countries (United Nations Industrial Development Organization, Vienna)

Gereffi G, Pan M, 1994, "The globalization of Taiwan's garment industry", in Global Production: The Apparel Industry in the Pacific Rim Eds E Bonacich, L Cheng, N Hamilton, P Ong (Temple University Press, Philadelphia, PA) pp $126-146$

Gereffi G, Garcia-Johnson R, Sasser E, 2001, “The NGO-industrial complex” Foreign Policy $12556-65$

Gereffi G, Humphrey J, Sturgeon T, 2005, “The governance of global value chains” Review of International Political Economy 1278 - 104

Grand National Assembly of Turkey, 2001 "T.B.M.M. Tutanak Dergisi Dönem 21”, T.B.M.M., Ankara, http://www.tbmm.gov.tr/tutanak/donem21/yil4/bas/b022m.htm

Hollingsworth J R, Schmitter P C, Streeck W (Eds), 1994 Governing Capitalist Economies: Performance and Control of Economic Sectors (Oxford University Press, New York)

Humphrey J, Schmitz H, 2001, "Governance and global value chains" IDS Bulletin 32 19-23

Humphrey J, Schmitz H, 2002, "How does insertion in global value chains affect upgrading in industrial clusters?" Regional Studies 361017 - 1027

Hurcks K, 1994, "Die Bedeutung des passiven Veredelungsverkehrs für die deutschen Textil- und Bekleidungshersteller - eine empirische Untersuchung" [The significance of outward processing for the German textile and garment industry], in Die Bedeutung des passiven Veredelungsverkehrs für den Textilstandort Deutschland [The significance of outward processing for Germany as a textile production site] Eds D Ahlert, G Dieckheuer (Marketinginstitut für Textilwirtschaft, Universität Münster, Münster) pp 4-47

Neidik B, 2004a Explaining Economic Performance in the Global Economy: Evidence from the Apparel Industries of Germany and Turkey unpublished $\mathrm{PhD}$ dissertation, Department of Sociology, Duke University, Durham, NC

Neidik B, 2004b, "Organizational foundations of export performance: the case of the Turkish apparel industry" Journal of Fashion Marketing and Management 8 279-299

Pickles J, 2002, "Gulag Europe? Mass unemployment, new firm creation, and tight labor markets in the Bulgarian apparel industry", in Work, Employment, and Transition: Restructuring Livelihoods in Past-communism Eds A Rainnie, A Smith, A Swain (Routledge, London) pp 246-272

Riddle L A, Gillespie K, 2003 "Information sources for new ventures in the Turkish clothing export industry" Small Business Economics 20105 - 120

Robinson T, Foot R, Clarke-Hill C M, 2000, "German retailing expansion-a decade of change?" European Business Review 12 216-224

Rothstein J S, 2005, "Economic development policymaking down the global commodity chain: attracting an auto industry to Silao, Mexico" Social Forces 84 49-69

Scheffer M, 1995 The EU Textile and Clothing Industry 1993/4: A Factual Report (Observatoire Européen du Textile et de l'Habillement, Brussels)

Schmitz H, Knorringa P, 2000, "Learning from global buyers" Journal of Development Studies $37177-205$

Smith A, Buček M, Pickles J, Begg B, 2003, "Global trade, European integration and the restructuring of Slovak apparel exports" Ekonomický časopis 51731 - 748

Smith A, Pickles J, Begg B, Roukova P, Buček M, 2004, "Upgrading the East European apparel industry: outsourcing and the 'embedded geographies' of production", paper presented for the conference 'Clothing Europe: Comparative Perspectives on Trade Liberalisation and Production Networks in the New European Clothing Industry, University of North Carolina, Chapel Hill, NC

SOMO, 2003, "Garment and textile production: focus on Turkey" SOMO Bulletin on Issues in Garment and Textiles number 3, http://www.somo.nl/html/paginas/pdf/3_Focus_on_Turkey_2003_EN.pdf

Terrahe C B, 1997 Vertikale Kooperationen in der Modebranche [Vertical cooperation in the fashion sector] BTE-Fachdokumentation number 66, Bundesverband des Deutschen Textileinzelhandels e.V., Köln

Tokatl N, 2003, "Globalization and the changing clothing industry in Turkey" Environment and Planning A $351877-1894$ 
Tokatlı N, Eldener Y B, 2004, "Upgrading in the global clothing industry: the transformation of Boyner Holding" Competition and Change $8173-193$

Tokatlı N, K1zılgün Ö, 2004, "Upgrading in the global clothing industry: Mavi Jeans and the transformation of a Turkish firm from full-package to brand name manufacturing and retailing" Economic Geography 80221 - 240

Tücking E, 1999 Die deutsche Bekleidungsindustrie im Zeitalter der Globalisierung: Eine Marktanalyse unter besonderer Berücksichtigung außenwirtschaftlicher Rahmenbedingungen [The German apparel industry in the age of globalization: a market analysis with special attention to the conditions of foreign trade] (FATM, Münster)

Werner International, 1998, "Spinning and weaving labour cost comparisons", Spring (Werner International, Reston, VA)

Wortmann M, 2003, "Structural change and the globalization of the German retail industry", discussion paper SP 32003 -202b, Wissenschaftszentrum Berlin für Sozialforschung, Berlin

Yaşar E, 1996 Türk Tekstil ve Konfeksiyon Sektörü [The Turkish textile and garment sector] (ITKİB, Istanbul) 
Conditions of use. This article may be downloaded from the E\&P website for personal research by members of subscribing organisations. This PDF may not be placed on any website (or other online distribution system) without permission of the publisher. 